Open access article, license CC BY-NC-ND

Issue IV, 22 November 2021

e-ISSN 2707-9481

Institute of Metallurgy and Ore Beneficiation, Satbayev University, Almaty, Kazakhstan

\author{
Gladyshev Sergey Vladilenovich \\ Institute of Metallurgy and Ore Beneficiation, \\ Satbayev University Almaty, Kazakhstan \\ Email: gladyshev.sergey55@mail.ru \\ ORCID ID: 0000-0002-4939-7323
}

\author{
Didik Nurhadiyanto \\ Universitas Negeri Yogyakarta, Yogyakarta, Indonesia \\ Email: didiknur@uny.ac.id \\ ORCID ID: 0000-0003-0643-0776
}

\title{
Disposal of copper electrofining solutions
}

\begin{abstract}
The paper presents studies of the processing of spent copper electrolyte from the processing of non-ferrous metal scrap at a copper smelter in Kazakhstan. For the processing of the spent electrolyte, a stage-by-stage neutralization was carried out using zinc sublimates and potash. As a result of the first stage of neutralization with zinc sublimations to $\mathrm{pH} 4.7$, a precipitate with a content of $\mathrm{PbO} 44.69 \%$; $\mathrm{PO}_{2} 16.36 \%$ was obtained. After processing the sediment with an alkaline solution, carbonization and melting at a temperature of $900{ }^{\circ} \mathrm{C}$, metallic lead and tin-containing slag with a content of SnO2 of $16.36 \%$ were obtained. As a result of the second stage of neutralization with potash to $\mathrm{pH} 7.1$, a precipitate was obtained-with a CuO content of $76.45 \%$. After the third stage of neutralization with potash to $\mathrm{pH} 9.5$, a precipitate with a content of $\mathrm{NiO} 27.63 \%$ and $\mathrm{ZnO} 55.75 \%$ was obtained. After treatment of the precipitate with a solution containing $100 \mathrm{~g} / \mathrm{dm}^{3} \mathrm{KOH}$, a zinc-containing solution with a ZnO content of $225.0 \mathrm{~g} / \mathrm{dm}^{3}$ and a precipitate were obtained, after calcination of which nickel oxide with a $\mathrm{NiO}$ content of $89.14 \%$ was obtained.
\end{abstract}

Keywords: copper electrolyte, zinc-containing product, potash, copper-containing precipitate, metallic lead, slag.

Cite this article as: Gladyshev S.V.; Nurhadiyanto D. (2021). Disposal of copper electrofining solutions. Challenges of Science. Issue IV, 2021, pp. 55-60. https://doi.org/10.31643/2021.08

\section{Introduction}

The processing of non-ferrous metal scrap is followed by an accumulation of foreign impurities of nickel, zinc, and others in the reversible electrolyte at the stage of obtaining electro refined copper; these impurities degrade the quality of cathode copper. Part of the electrolyte from commercial baths is periodically removed from the electrolysis cycle and processed. Enterprise productivity depends on solution processing therefore the development of effective technology is urgent.

When refined copper is received from mineral raw materials, the reversible electrolyte is regenerated. The following methods have been proposed to purify the electrolyte from impurities, i.e. extraction, sorption, membrane, and combined sorption-electrochemical ones $[3,5,6,10,11]$.

Most non-ferrous metal scrap processing plants use a two-stage scheme of spent electrolyte processing that includes evaporation and crystallization to obtain copper sulfate and extraction of residual copper from the evaporated solution by electroextraction $[4,11]$. As soon as copper has been extracted from the solution, evaporation, crystallization, and subsequent refining are applied to extract nickel in the form of a sulfuric acid salt. The method does not make it possible to selectively isolate the non-ferrous metals present in the solution.

There is a method of processing the spent electrolyte whereby copper is first extracted through electroextraction. After electroextraction, the solution is neutralized with lime white to obtain a gypsum nickel-containing cake or evaporated to release a cake containing metal sulfates $(\mathrm{Cu}, \mathrm{Ni}, \mathrm{Zn}, \mathrm{Fe})$ that are sold as a marketable product $[1,2,4,11]$. Obtaining selectively separated non-ferrous metals by this method is also impossible. 
The research designed to utilize solutions and selectively separate non-ferrous metal concentrates by stage neutralization using a zinc-containing industrial product took place to solve the problem of developing an effective technology for processing spent copper electrolyte.

A zinc-containing industrial product, namely, zinc sublimation, is formed during the processing of non-ferrous metal scrap in the course of fire refining of copper and is captured during the purification of exhaust gases in bag filters. Such sublimations are mixed with sulfur-containing flux, granulated, and distilled with lead and tin in a rotary furnace $[7,8,12]$.

\section{Research methods and techniques}

A Venus 200 wave dispersion spectrometer (PANalyical B.V., the Netherlands) was used to perform an X-ray fluorescence analysis.

The samples were subjected to chemical analysis with the help of an optical emission spectrometer with an inductively coupled plasma Optima 2000 DV (USA, Perkin Elmer).

The semi-quantitative X-ray phase analysis was based on a D8 Advance diffractometer (BRUKER) with copper $\mathrm{Cu}-\mathrm{K} \alpha$ radiation at an accelerating voltage of $36 \mathrm{kV}$ and a current of $25 \mathrm{~mA}$.

A low-vacuum electron microscope with a thermoemission cathode $\left(\mathrm{LaB}_{6}\right) \mathrm{JSM}-6610 \mathrm{LV}$ from JEOL was applied to take microphotographs.

\section{Research results}

The study was based on the spent electrolyte of copper and zinc sublimation from the copper smelting plant of Casting LLP in Kazakhstan.

Chemical composition of the spent copper electrolyte, wt. g/ $\mathrm{dm}^{3}$ : Cu 67.14; Ni 36.41; Fe 11.43; Zn 10.96; $\mathrm{SO}_{4}$ 125.9; N 4.1; As; 0.03; Bi 0.002; At 2.6; Pb 0.014; Sb 0.05; Si 0.047; Sn 0.0.

Chemical composition of the zinc sublimation wt. \%: $\mathrm{F} \mathrm{0.97,} \mathrm{Al}_{2} \mathrm{O}_{3} \quad 0.15, \mathrm{P}_{2} \mathrm{O}_{5} 0.82, \mathrm{SO}_{3} 4.0, \mathrm{Cl} 11.64$, $\mathrm{K}_{2} \mathrm{O}$ 0.93, $\mathrm{CaO} 0.36, \mathrm{Fe}_{2} \mathrm{O}_{3} 0.29, \mathrm{NiO} 0.05, \mathrm{CuO} 7.86, \mathrm{ZnO} 39.46, \mathrm{Br} 0.19, \mathrm{MoO}_{3} 0.1, \mathrm{CdO} 0.23, \mathrm{SnO}_{2}$ 7.16, $\mathrm{WO}_{3} 0.36, \mathrm{PbO} 19.4, \mathrm{Bi}_{2} \mathrm{O}_{3} 0.04$, p.p. 0.04 .

Figure 1 illustrates the electron microscopic analysis of zinc sublimation.
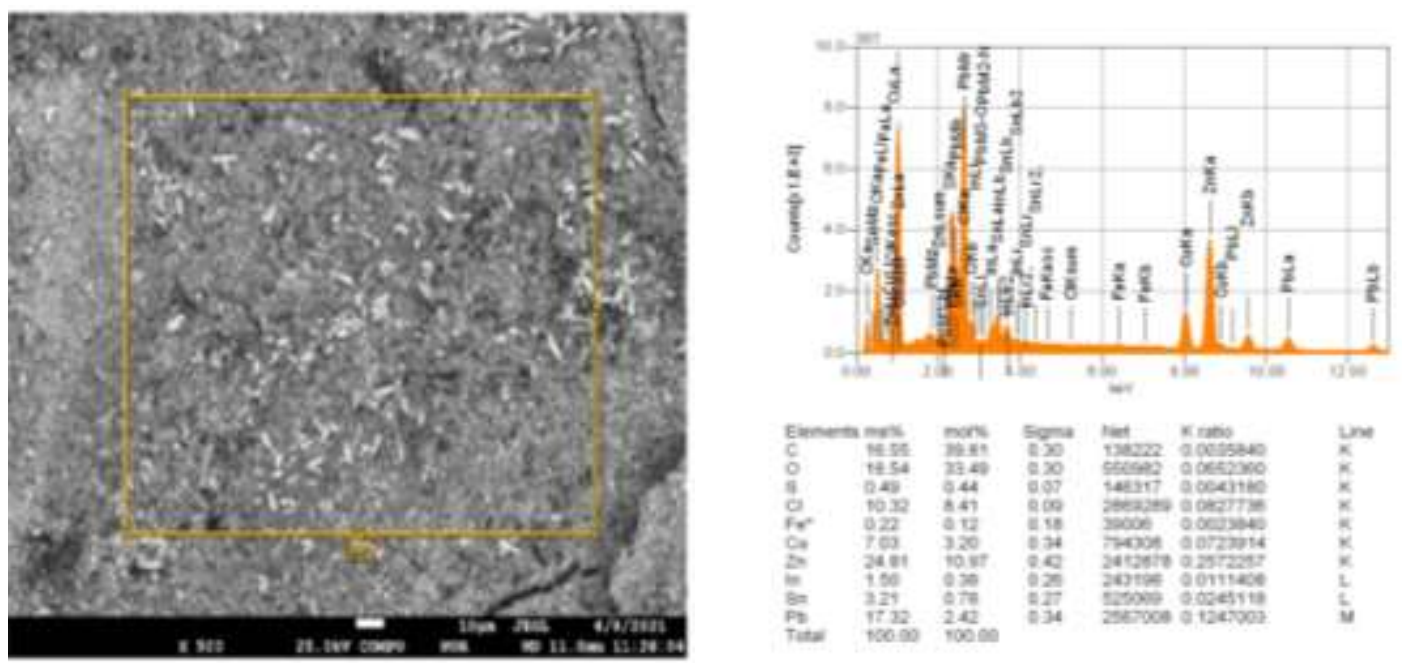

Figure 1. Microphotograph of zinc sublimation x 500

According to the $\mathrm{X}$-ray phase analysis presented in Figure 2, the zinc sublimation composition is as follows, wt. \%: matlokite (PbClF) - 43.1; copper sulfate $\left(\mathrm{Cu}_{5}\left(\mathrm{SO}_{4}\right)_{2}(\mathrm{OH})_{6} \cdot 5 \mathrm{H}_{2} \mathrm{O}\right)-20.0$; copper chlorate $\left(\mathrm{Cu}\left(\mathrm{ClO}_{4}\right)_{2}\right)$ - 10.3; zinc stonate $\left(\mathrm{Zn}_{2}\left(\mathrm{SnO}_{4}\right)\right)-9.8$; moolooit $\left(\mathrm{C}_{2} \mathrm{CuO}_{4} \cdot \mathrm{xH}_{2} \mathrm{O}\right)-4.4$; lead acetate hydroxide hydrate $\left(\mathrm{C}_{4} \mathrm{H}_{8} \mathrm{~Pb}_{2} \mathrm{O}_{6} \cdot \mathrm{H}_{2} \mathrm{O}\right)-3.8$; zinc oxalate $\left(\mathrm{C}_{2} \mathrm{O}_{4} \mathrm{Zn}\right)-3.2$; fedotovite $\left(\mathrm{K}_{2} \mathrm{Cu}_{3}+2 \mathrm{O}\left(\mathrm{SO}_{4}\right)_{3}\right)-2.8$, and zinc chloride $\left(\mathrm{ZnCl}_{2}\right)-2.6$. 


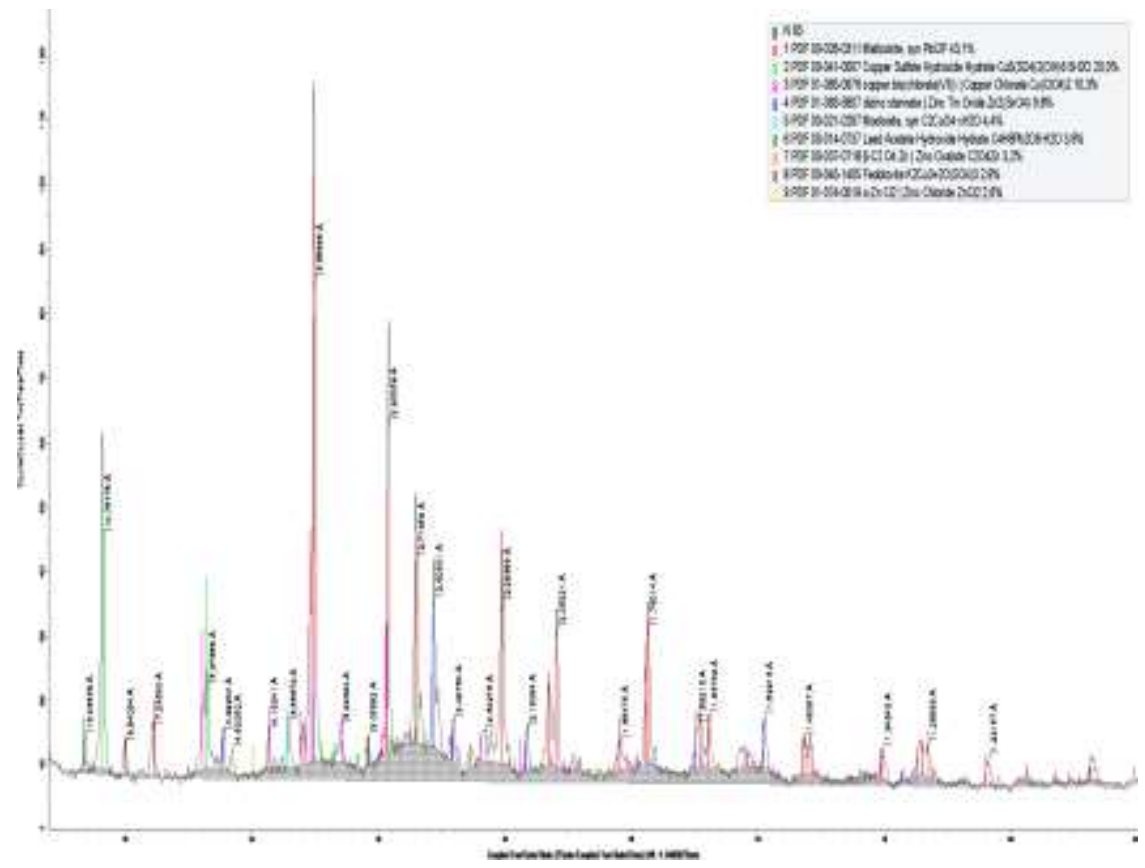

Figure 2. Radiograph of the zinc sublimation

To utilize industrial products resulting from the processing of non-ferrous metal scrap and selective separation of non-ferrous metals, stage neutralization of the spent copper electrolyte with the use of zinc sublimations was applied.

The first stage of electrolyte neutralization included zinc sublimation to $\mathrm{pH} 4.7$ at $\mathrm{S}: \mathrm{L}=5: 1$, temperature $-20^{\circ} \mathrm{C}$, stirring time -3 hours. Neutralization provided a black lead-tin-containing sludge, the composition of which is shown in Table 1.

The second and third stages of neutralization included potash. Potash was chosen instead of the cheaper reagent $\mathrm{Na}_{2} \mathrm{CO}_{3}$ due to the possible obtaining of a commercial, highly liquid product - potassium sulfate $\mathrm{K}_{2} \mathrm{SO}_{4}$, instead of $\mathrm{Na}_{2} \mathrm{SO}_{4}$, after purification of the solution and its evaporation.

After the second stage of the electrolyte neutralization to $\mathrm{pH}$ 7.1, a copper-containing sludge with a low content of impurities is obtained and it may be returned to the copper electrorefining solution.

Table 1. Chemical composition of the neutralization sludges

\begin{tabular}{|c|c|c|c|}
\hline \multirow[t]{3}{*}{ Name } & \multicolumn{3}{|c|}{ Content, \% } \\
\hline & \multicolumn{3}{|c|}{$\mathrm{pH}$} \\
\hline & 4.7 & 7.1 & 9.5 \\
\hline $\mathrm{F}$ & 0.44 & 0.26 & 0.3 \\
\hline $\mathrm{Na}_{2} \mathrm{O}$ & 0.71 & - & - \\
\hline $\mathrm{MgO}$ & - & - & 0.11 \\
\hline $\mathrm{Al}_{2} \mathrm{O}_{3}$ & 1.56 & 0.34 & 1.3 \\
\hline $\mathrm{SiO}_{2}$ & 4.08 & 0.24 & 0.54 \\
\hline $\mathrm{P}_{2} \mathrm{O}_{5}$ & 0.41 & 0.01 & 0.009 \\
\hline $\mathrm{SO}_{3}$ & 11.12 & 5.56 & 3.42 \\
\hline $\mathrm{Cl}$ & 0.72 & 4.7 & 0.19 \\
\hline $\mathrm{K}_{2} \mathrm{O}$ & 0.19 & - & 0.05 \\
\hline $\mathrm{CaO}$ & 0.85 & 0.03 & 0.38 \\
\hline $\mathrm{Fe}_{2} \mathrm{O}_{3}$ & 5.48 & 0.31 & 0.14 \\
\hline $\mathrm{NiO}$ & 0.15 & 1.1 & 27.63 \\
\hline $\mathrm{CuO}$ & 2.97 & 76.45 & 0.68 \\
\hline
\end{tabular}




\begin{tabular}{lccc}
\hline $\mathrm{ZnO}$ & 4.79 & 2.8 & 55.75 \\
\hline $\mathrm{Br}$ & 0.09 & 0.01 & - \\
\hline $\mathrm{MoO}_{3}$ & 0.23 & - & - \\
\hline $\mathrm{CdO}$ & 0.08 & 0.01 & - \\
\hline $\mathrm{SnO}_{2}$ & 16.36 & - & - \\
\hline $\mathrm{WO}_{3}$ & 0.29 & - & - \\
\hline $\mathrm{PbO}^{2}$ & 44.69 & 0.06 & - \\
\hline $\mathrm{Bi} \mathrm{O}_{3}$ & 0.09 & - & 5.131 \\
\hline p.p. & 4.7 & 5.12 & 100 \\
\hline Total & 100 & 100 \\
\hline
\end{tabular}

The sludge obtained from the first stage of neutralization was treated with a solution of spent electrolyte at a ratio of $\mathrm{S}: \mathrm{L}=10: 1$. This resulted in a filtrate with a $\mathrm{pH}$ of 2.2 and a lead-tin-containing product of the following composition, wt. \%: $\mathrm{Na}_{2} \mathrm{O} 0.16 ; \mathrm{Al}_{2} \mathrm{O}_{3} 0.34 ; \mathrm{SiO}_{2} 1.83 ; \mathrm{P}_{2} \mathrm{O}_{5} 0.17 ; \mathrm{SO}_{3} 20.53 ; \mathrm{Cl} 0.51$; $\mathrm{K}_{2} \mathrm{O}$ 0.29; $\mathrm{CaO} 0.23 ; \mathrm{Fe}_{2} \mathrm{O}_{3}$ 0.95; $\mathrm{NiO} 0.05 ; \mathrm{CuO} 1.33 ; \mathrm{ZnO} 0.57 ; \mathrm{As}_{2} \mathrm{O}_{3} 0.07 ; \mathrm{Br} 0.07 ; \mathrm{MoO}_{3} 0.1 ; \mathrm{CdO} 0.1 ; \mathrm{SnO}_{2}$ 9.5; $\mathrm{WO}_{3}$ 0.18; $\mathrm{PbO} 62.24 ; \mathrm{BiO}_{3}$ 0.11; p.p. 0.67 .

To process the obtained product, a method of processing lead-containing production waste was used [9]. The method is suitable for processing lead-containing production wastes containing compounds of tin, antimony, copper, iron, zinc, bismuth, arsenic, silver, calcium, sodium, and potassium.

In accordance with [9], the obtained lead-tin product was carbonized in a solution containing 135 $\mathrm{g} / \mathrm{dm}^{3}$ of $\mathrm{K}_{2} \mathrm{CO}_{3}$, at $\mathrm{S}: \mathrm{L}=4: 1$, and a temperature of $20^{\circ} \mathrm{C}$. After filtration, a sludge of the following composition was obtained, wt. \%: $\mathrm{Al}_{2} \mathrm{O}_{3} 0.42 ; \mathrm{SiO}_{2} 2.29 ; \mathrm{P}_{2} \mathrm{O}_{5} 0.21 ; \mathrm{SO}_{3} 2.9 ; \mathrm{Cl} 0.1 ; \mathrm{K}_{2} \mathrm{O} 0.29 ; \mathrm{CaO} 0.23 ; \mathrm{Fe}_{2} \mathrm{O}_{3}$ 0.95; $\mathrm{NiO}$ 0.06; $\mathrm{CuO}$ 1.66; $\mathrm{ZnO} 0.71 ; \mathrm{As}_{2} \mathrm{O}_{3}$ 0.1; $\mathrm{Br} 0.01 ; \mathrm{MoO}_{3} 0.12 ; \mathrm{SnO}_{2} 11.8 ; \mathrm{WO}_{3}$ 0.22; $\mathrm{PbO} 77.8 ; \mathrm{BiO}_{3}$ 0.13 .

The phase composition of the carbonization sludge is as follows, wt. \%: cerussite $\left(\mathrm{PbCO}_{3}\right)-91.4$; ferrous tin oxide $\left(\left(\mathrm{Sn}_{0.9} \mathrm{Fe}_{0.1}\right) \mathrm{O}_{2}\right)-3.0$; cassiterite $\left(\mathrm{SnO}_{2}\right)-2.8$; ferrosilite $\left(\mathrm{Fe}_{3} \mathrm{Si}_{0.93}\right)-1.5$, and zinc oxide $(\mathrm{ZnO})-1.3$ (Figure 3).

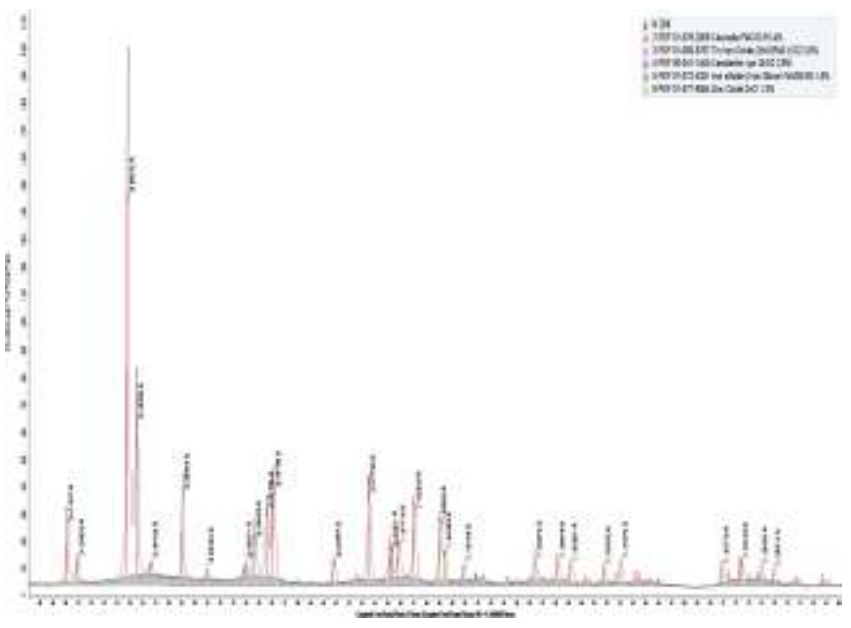

Figure 3. Radiograph of the sludge after carbonization

The carbonization sludge in a mixture of $10 \%$ charcoal and $5 \% \mathrm{~K}_{2} \mathrm{CO}_{3}$ was melted at a temperature of $900^{\circ} \mathrm{C}$ for 30 minutes. A metallic lead-tin-containing slag of the following composition was obtained, wt. \%: $\mathrm{PbO}$ 3.36; $\mathrm{SnO}_{2} 47.84 ; \mathrm{Al}_{2} \mathrm{O}_{3}$ 1.08; $\mathrm{SiO}_{2}$ 9.2; $\mathrm{P}_{2} \mathrm{O}_{5}$ 1.96; $\mathrm{SO}_{3}$ 0.54; $\mathrm{K}_{2} \mathrm{O}$ 15.1; $\mathrm{CaO} 2.7 ; \mathrm{Fe}_{2} \mathrm{O}_{3}$ 4.8; $\mathrm{NiO} 0.64 ;$ $\mathrm{CuO}$ 5.5; $\mathrm{ZnO} 0.3 ; \mathrm{As}_{2} \mathrm{O}_{3}$ 0.6; $\mathrm{WO}_{3}$ 3.0; p.p. 3.38 .

The third stage of the spent electrolyte neutralization to $\mathrm{pH} 9.5$ provided nickel-zinc-containing sludge (Table 1). The sludge was treated with a solution containing $100 \mathrm{~g} / \mathrm{dm}^{3}$ of $\mathrm{KOH}$ at $\mathrm{S}: \mathrm{L}=3: 1$ and a temperature of $90^{\circ} \mathrm{C}$ for 30 minutes. An alkaline zinc-containing solution with a $\mathrm{ZnO}$ content of $225.0 \mathrm{~g} / \mathrm{dm}^{3}$ and a nickel-containing sludge of the following composition was obtained, wt. \%: $\mathrm{NiO} 76.2 ; \mathrm{MgO} 3.2 ; \mathrm{Al}_{2} \mathrm{O}_{3}$ $0.32 ; \mathrm{SiO}_{2} 0.35 ; \mathrm{SO}_{3} 0.31 ; \mathrm{CaO} 1.4 ; \mathrm{Fe}_{2} \mathrm{O}_{3} 0.11 ; \mathrm{CuO} 0.2 ; \mathrm{ZnO} 0.5 ;$ p.p. 17.41 . 
After the sludge calcination at a temperature of $350^{\circ} \mathrm{C}$ for 30 minutes, a nickel oxide sludge of the following composition was obtained, wt. \%: $\mathrm{MgO} 5.44 ; \mathrm{Al}_{2} \mathrm{O}_{3}$ 0.54; $\mathrm{SiO}_{2} 0.59 ; \mathrm{SO}_{3} 0.53 ; \mathrm{CaO} 2.38 ; \mathrm{Fe}_{2} \mathrm{O}_{3} 0.19$; $\mathrm{NiO} 89.14 ; \mathrm{CuO} 0.34 ; \mathrm{ZnO} 0.85$.

The conducted researches resulted in developing the technological processing scheme for the spent copper electrolyte with the use of zinc sublimations for neutralization (Figure 4).

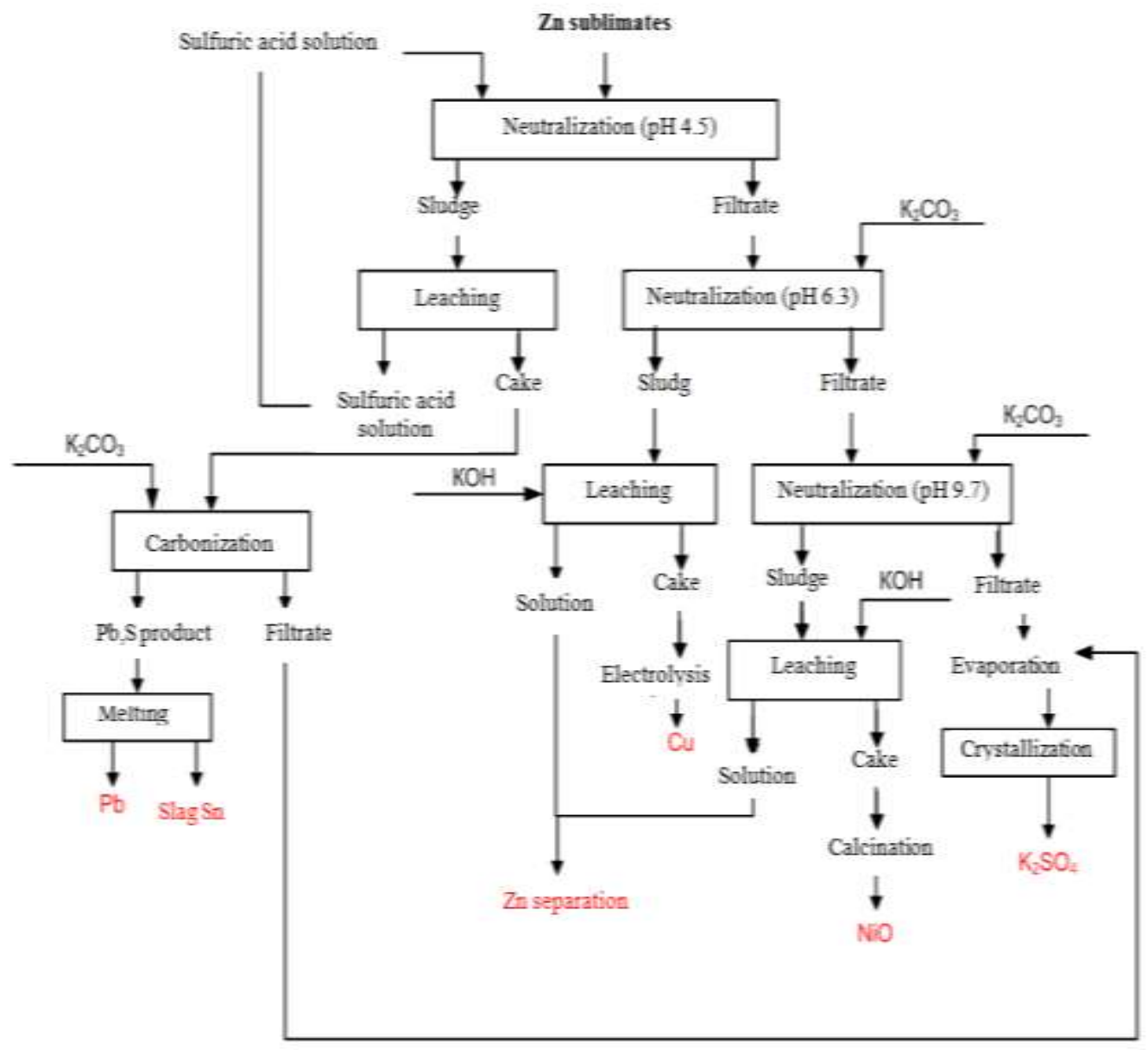

Figure 4. Technological processing scheme for the spent copper electrolyte obtained from the production of nonferrous metal scrap

\section{Conclusions}

A staged neutralization of the spent electrolyte obtained from the electrorefined copper of processing of non-ferrous metal scrap by zinc sublimations and potash provided a copper-containing sludge of nickel oxide, alkaline zinc-containing solution, and metallic lead-tin-containing slag.

The technological scheme intended for use of industrial products resulting from the processing of non-ferrous metal scrap - the spent electrolyte and zinc sublimations - has been developed.

\section{Acknowledgments}

This work was based on grant financing \#AP09259315 and supported by the Committee of Science of the Ministry of Education and Science of the Republic of Kazakhstan.

Cite this article as: Gladyshev S.V.; Nurhadiyanto D. (2021). Disposal of copper electrofining solutions. Challenges of Science. Issue IV, 2021, pp. 55-60. https://doi.org/10.31643/2021.08 


\section{References}

1 Altaybaev B.T., Khabiev A.T., Baigenzhenov O.S., Bulenbaev M.Zh., Turan M.D. (2020) Extraction of copper from solutions of agitational leaching of lead dust by liquid extraction (2020).// Complex use of mineral raw materials. Kompleksnoe Ispol'Zovanie Mineral'Nogo syrââ/Complex Use of Mineral Resources/Mineraldik Shikisattardy Keshendi Paidalanu, 3 (2020), - P. 5055. https://doi.org/10.31643/2020/6445.26 (in Eng.)

2 Vasiliev A. A., Urlapkina N. N. Mineev G. G. Extraction purification of copper electrolyte from arsenic // Bulletin of the Irkutsk State Technical University. - 2017. Vol. 21. - No. 11. - pp. 160-168. https://doi.org/ 10.21285/1814-3520-2017-10-160-168. (in Russ.)

3 Levin A.M., Bryukvin V. A. On the use of a reverse osmotic installation for the utilization of nickel-cobalt industrial effluents and washing waters / / Non-ferrous metals. - 2010. - No. 12. - pp. 32-33. ISSN: 0372-2929 http://www.rudmet.ru/journal/432/article/3638/ (in Russ.)

4 Napolskikh Yu. A. Extraction of heavy non-ferrous metals from sludge neutralization of spent electrolytes: Master's thesis: 31.05.2018. - Ural Federal University named after the first President of Russia B. N. Yeltsin, Yekaterinburg, 2018-98 p. http://hdl.handle.net/10995/65160 (in Russ.)

5 Olshanskaya L. N. Sobgaida N. A. Valiev R. S. Extraction of heavy metals from polluted effluents using adsorbents and phytosorbents // Ecology and industry of Russia. -2015. - Vol. 19. - No. 11 - - p. 18-23. https://doi.org/10.18412/1816-0395-201511-18-23 (in Russ.)

6 Pashkov G. L., Fleitlich I. Yu., Kholkin A. I., Luboshnikova K. S., Sergeev V. V., Kopanev A.M., Grigorieva N. A., Nikiforova L. K. Development and development of extraction processes at the Norilsk Mining and Metallurgical Combine / / Chemistry in the interests of sustainable development. - 2010. - No. 3. - pp. 355-364. (The impact factor of the RSCl 2017 is 0.532). https://www.sibran.ru/upload/iblock/48d/48dc19aada01162d949597e4b6272286.pdf (in Russ.)

7 Patent No. 3336131 JP MPK7 C22B19/04, C22B7/02. A method for extracting zinc from zinc-containing dust waste / Sato Kazuhiko; others: 03. - Publ. 21.10.2002 (in Russ.)

8 Patent No. 3336167 JP MPK7 C22B19/04, C22B7/02. Method of processing dust waste of an electric furnace / Sato Kazuhiko; others: 03. - Publ. 21.10.2002. (in Russ.)

9 Patent of the Russian Federation 2294972. A method for processing lead-containing industrial waste/ Letov A.V., Kan A.V. publ. 10.03.2007. (in Russ.)

10 Taranovskaya E. A. Sobgaida N. A., Morev P. A. Composite materials for wastewater treatment from heavy metal ions / / Materials of the XIII International Scientific and Practical Conference "Tatishchevsky readings: actual problems of science and practice". In 5 t. - Togliatti. - 2016. - pp. 217-220. https://doi.org/ 10.21285/1814-3520-2017-10-160-168. (in Russ.)

11 Utilization and complex processing of products and waste of gas purification of copper-nickel production / A. G. Kasikov, N. S. Areshina. - Apatity: FITC KNC RAS, 2019 - -196 p.: il. ISBN 978-5-91137-410-5. https://DOI: 10.25702/KSC.978.5.91137.410.5 (in Russ.)

12 Zhunussova G., Kalyanova O., Taimassova A., Altaibayev B., Jumankulova S. Cementation of copper, cadmium, cobalt and nickel from zinc containing sulphate solutions after pressure leaching of zinc-containing wastes. 5th International Scientific Conference «Science and Society». - 25-26 November 2013, London, p. 83-89. http://scieuro.com/ru/category/books / (in Eng.) 